\title{
Effectiveness, Safety, and Major Adverse Limb Events in Atrial Fibrillation Patients with Concomitant Diabetes Mellitus Treated with Non-Vitamin K Antagonist Oral Anticoagulants
}

\section{Yi-Hsin Chan}

Chang Gung Memorial Hospital

Hsin-Fu Lee

Chang Gung Memorial Hospital

Pei-Ru Li

Chang Gung University

Jia-Rou Liu

Chang Gung University

Tze-Fan Chao

Taipei Veterans General Hospital

Lung-Sheng Wu

Chang Gung Memorial Hospital

Shang-Hung Chang

Chang Gung Memorial Hospital

Yung-Hsin Yeh

Chang Gung Memorial Hospital

Chi-Tai Kuo

Chang Gung Memorial Hospital

Lai-Chu See ( $\square$ lichu@mail.cgu.edu.tw)

Gregory Y. H. Lip

Liverpool Heart and Chest Hospital

Original investigation

Keywords: atrial fibrillation, diabetes mellitus, ischemic stroke, major bleeding, NOACs, warfarin

Posted Date: March 2nd, 2020

DOI: https://doi.org/10.21203/rs.3.rs-15546/v1

License: (c) (1) This work is licensed under a Creative Commons Attribution 4.0 International License. Read Full License 
Version of Record: A version of this preprint was published at Cardiovascular Diabetology on May 13th, 2020. See the published version at https://doi.org/10.1186/s12933-020-01043-2. 


\section{Abstract}

Background: Evidence of adverse clinical outcomes for non-vitamin $\mathrm{K}$ antagonist oral anticoagulant (NOACs) and warfarin in patients with atrial fibrillation (AF) and diabetes mellitus are limited. We investigated the effectiveness, safety, and major adverse limb events for NOACs versus warfarin among diabetic AF patients.

Methods: In this nationwide retrospective cohort study collected from Taiwan National Health Insurance Research Database, we identified a total of 20,967 and 5,812 consecutive AF patients with diabetes taking NOACs and warfarin from June 1, 2012, to December 31, 2017, respectively. We used propensity-score stabilized weighting to balance covariates across study groups.

Results: NOAC was associated with a lower risk of major adverse cardiovascular events (MACE) (adjusted hazard ratio (aHR):0.88; [95\% confidential interval $(\mathrm{Cl})$ :0.78-0.99]; $P=0.0283$ ), major adverse limb events (aHR:0.72;[95\%Cl:0.57-0.92]; P =0.0083), and major bleeding (aHR:0.67;[95\%Cl:0.59-0.76]; $\mathrm{P}<.0001$ ) compared to warfarin. NOACs decreased MACE in patients of 75 but not in those aged $<75$ years ( $P$ interaction $=0.01)$, and in patients with ischemic heart disease $(I H D)$ compared to those without IHD ( $P$ interaction $<0.01$ ). For major adverse limb events, the advantage of risk reduction for NOAC over warfarin persisted in high risk subgroups including age 75 years, chronic kidney disease, IHD, peripheral artery disease, or use of concomitant antiplatelet drugs.

Conclusion: NOACs were associated with a lower risk of effectiveness, safety, and major adverse limb events than warfarin among diabetic AF patients. Thromboprophylaxis with NOACs should be considered in the diabetic AF population with a high atherosclerotic burden.

\section{Background}

Atrial fibrillation (AF) is the most common cardiac arrhythmia globally, and is associated with a five-fold increased risk of stroke compared to patients without AF.[1] Diabetes mellitus (DM) is an important risk factor of ischemic stroke and the development of new onset AF.[2] Around $40 \%$ AF patients have comorbid DM, and both are associated with a higher risk of ischemic stroke, acute coronary syndrome, and cardiovascular events.[3]

Current international guidelines recommend the use of non-vitamin $\mathrm{K}$ antagonist oral anticoagulants (NOACs) as effective, safer and more convenient alternatives to warfarin among patients with non-valvular $A F$, including those with DM. $[4,5]$ However, in post hoc analyses of the landmark NOACs trials, the safety profiles for dabigatran $110 \mathrm{mg}$ or apixaban $5 / 2.5 \mathrm{mg}$ over warfarin were diminished in AF patient comorbid with DM.[6, 7] Specifically, there were no clear benefits of NOACs over warfarin with regard toding the risk of major bleeding in diabetic AF patients. In recent non-AF studies, $[8,9]$ the value of NOACs in reducing major adverse limb events in patients at high vascular risk is also apparent.

In this study, we investigated the effectiveness, safety, and major adverse limb events for NOACs versus warfarin among diabetic AF patients, using a large population-based nationwide cohort study. 


\section{Methods}

We performed a retrospective nationwide cohort study using the Taiwan National Health Insurance Research Database (NHIRD), which contained health care information of more than 23 million Taiwan residents with a $>99 \%$ coverage rate of the entire population.[10] The NHIRD database contains each patient's demographic data, outpatient clinic visits, hospitalizations, interventions and examinations, drug prescriptions, records of outpatient visits, and diagnosis of diseases. By using a consistent encrypting procedure, the original identification number of each patient in the NHIRD is encrypted and de-identified to protect patient privacy; therefore, informed consent was waived in the present study. This study was approved by the Institutional Review Board of the Chang Gung Medical Foundation (104-8079B and 201801427B0).

\section{Study design}

The study identified a total of 296,162 patients diagnosed with AF using (International Classification of Diseases (the ninth revision) Clinical Modification (ICD-9-CM) codes (427.31) between January 1, 2010 and December 31, 2015 or using ICD-10-CM codes (I48)) between January 1, 2016 and December 31, 2018. A total of 92,272 AF patients treated with oral anticoagulants (OACs) after June 1, 2012 were identified. In order to establish a non-valvular AF cohort treated with OACs for stroke prevention, those patients with a diagnoses indicating deep vein thrombosis or pulmonary embolism, mitral stenosis, post valvular surgery, or joint replacement therapy within 6 months before the index date were excluded. Patients with end-stage renal disease were also excluded because NOACs are absolutely contraindicated in dialyzed patients in Taiwan. Finally, we included 85,641 non-valvular AF patients treated with OACs from June 1, 2012 to December 31, 2017. After excluding 58,864 non-valvular AF patients without a diagnosis of DM, a total of 20,967 and 5,812 non-valvular AF patients comorbid with DM treated with NOACs and warfarin, respectively, were enrolled. The index date was defined as the first date of prescription for NOACs or warfarin. The follow-up period was defined as the duration from the index date until the first occurrence of any study outcome independently, or until the end date of the study period (December 31, 2017), whichever came first. A flowchart of the study enrollment is shown in Fig. 1.

\section{Study outcomes}

We reported several outcomes in the present study: (i) effectiveness outcomes: ischemic stroke/systemic embolism (IS/SE), acute myocardial infarction (AMI), and major adverse cardiac events (MACE) (defined as IS/SE or AMI); (ii) major lower limb outcomes: acute or chronic limb ischemia requiring revascularization procedures, lower limb amputation, and major adverse limb events (MALE) (defined as lower limb revascularization or amputation); (iii) safety outcomes: intracranial hemorrhage (ICH), major gastrointestinal bleeding, other critical site bleeding, and all major bleeding events. All major bleeding events are defined as the summation of hospitalized events of $\mathrm{ICH}$, major gastrointestinal bleeding, and other sites of critical bleeding. All study outcomes should be the primary discharge diagnosis to avoid misclassification. The diagnosis codes of NHIRD were shifted from ICD-9-CM to ICD-10-CM after January 1, 2016. The ICD-9-M and ICD-10-CM codes used to identify the baseline covariates and the study outcomes are summarized in

Supplemental Table I. Patients may have had the same outcomes more than once during the study duration, but we only considered the same study outcome that occurred first. 


\section{Covariates}

Baseline covariates were obtained from any claim records with the diagnoses, medications, or procedures codes prior to the index date. A history of any prescription medicine was confined to medications taken at least once within 3 months before the index date. The definition of concomitant use of antiplatelet agent (APT) including aspirin, clopidogrel, ticlopidine, or ticagrelor was defined as APT duration > 3 months after drug index date. Bleeding history was confined to events within 6 months before the index date. The $\mathrm{CHA}_{2} \mathrm{DS}_{2}$-VASc score (congestive heart failure, hypertension, age 75 years or older for 2 points, DM, previous stroke or transient ischemic attack for 2 points, vascular disease, age 65 to 74 years, and female gender) was computed to predict the risk of thromboembolism in AF patients, [11]. The HAS-BLED score (hypertension, abnormal renal or liver function, stroke, bleeding history, labile INR, age 65 years or older, and APT or alcohol use) was computed to predict the risk of bleeding in AF patients treated with OACs.[12]

\section{Statistical analysis}

We used the method of propensity score stabilized weights (PSSWs) to balance the differences in baseline characteristics across the study groups.[13] The advantage of PSSWs is to provide an appropriate estimate of the main effect variance and to maintain the designated type I error by preserving the sample size of the original data. The PSSWs among study groups were obtained using the generalized boosted model (GBM), which can automatically determine the best functions of covariates, including interactions or polynomial terms, to obtain the optimal balance among study groups.[14] The advantage of PSSWs obtained by GBM is less affected by large weights.[14] All covariates in Table 1 except for $\mathrm{CHA}_{2} \mathrm{DS}_{2}$-VASc and HAS-BLED scores were included in the GBM, because $\mathrm{CHA}_{2} \mathrm{DS}_{2}$-VASc and HAS-BLED scores were already a combination of other covariates. The balance of potential confounders at baseline (index date) between each study group was assessed using the absolute standardized mean difference (ASMD) rather than statistical testing, because balance is a property of the sample and not of an underlying population. The value of ASMD $\leq 0.1$ indicated an insignificant difference in potential confounders between the two study groups.[15] The incidence rates were computed using the total number of study outcomes during the follow-up period divided by person-years at risk. The risk of study outcomes for NOACs versus warfarin (reference) was obtained using survival analysis (Cox proportional hazards model for multivariate analysis). Subgroup analysis was performed to test whether the NOAC group continued to have a lower risk of clinical outcomes than the warfarin group in specific subgroup. It is noted that the PSSWs were re-estimated for each subgroup analysis so that the NOAC and warfarin subgroup maintained a balance of varied covariates across groups. Statistical significance was defined as a P-value $<0.05$. All statistical analyses were performed using SAS 9.4 (SAS Institute Inc., Cary, NC, USA).

\section{Results}

We identified a total of 20,967 and 5,812 diabetic non-valvular AF patients treated with NOACs and warfarin, respectively. Among the NOAC group, there were $16 \%, 31 \%, 6 \%$, and $47 \%$ patients taking apixaban, dabigatran, eodxaban, and rivaroxaban, respectively (Fig. 1). Before PSSW, the NOAC group was older, and had a higher prevalence of hypertension, dyslipidemia, and stroke history than the warfarin group (ASMD > 
0.1) (Table 1). The NOAC group also had a higher $\mathrm{CHA}_{2} \mathrm{DS}_{2}$-VASc and HAS-BLED score than the warfarin group before PSSW. After PSSW, both study groups were well-balanced in most characteristics (all ASMD < 0.1) (Table 2).

For the effectiveness outcome, the NOAC group had a lower risk of MACE $(P=0.0283)$ when compared to the warfarin group after PSSW. For the major lower limb outcomes, DOAC was associated with a lower risk of lower limb amputation $(P=0.0003)$ and MALE $(P=0.0083)$ than warfarin. For the safety outcomes, NOAC was associated with a lower risk of ICH $(P<.0001)$, major gastrointestinal bleeding $(P=0.0123)$, and all major bleeding $(P<.0001)$ than warfarin (Fig. 2).

\section{Subgroup analysis of different NOACs versus warfarin}

Subgroup analysis was performed to determine whether different NOACs were superior to warfarin regarding to the effectiveness, major adverse limb events, and safety among subgroups. There were $66 \%, 89 \%, 68 \%$, and $95 \%$ patients taking low-dose apixaban ( $2.5 \mathrm{mg}$ twice daily), dabigatran (110 mg twice daily), eodxaban (30 mg daily), and rivaroxaban (15/10 mg daily) among the NOAC group, respectively. In general, the advantage of effectiveness, major limb outcome, and safety for NOAC over warfarin persisted in four NOAC subgroup (P interaction all > .05) (Fig. 3).

\section{Subgroup analysis}

In general, the subgroup analysis showed consistent results for MACE, MALE, and all major bleeding for NOACs versus warfarin among those patients with $\geq 75$ years of age, the presence of chronic kidney disease (CKD), ischemic heart disease (IHD), peripheral artery disease (PAD), and use of concomitant APT consistent with the main analysis (Fig. 4). NOACs decreased the risk of MACE in patients aged $\geq 75$ years of age but not in patients of $<75$ years of age $(P$ interaction $=0.01$ ) and in patients with concomitant IHD than in those without concomitant IHD (P interaction $<0.01)$. For the subgroup analysis of patients taking concomitant APT, there was a lower risk of major bleeding for NOAC versus warfarin especially in the APT (-) subgroup (P interaction $=0.02$ ).

\section{Discussion}

To our best knowledge, this is the largest population-based study to investigate the effectiveness, safety, and major limb outcomes for the four NOACs vs. warfarin in Asian population comorbid with AF and DM. Our results indicated that NOACs were associated with a lower risk of MACE, MALE, and all major bleeding when compared to warfarin among AF patients comorbid with DM. Second, the advantage of effectiveness, major limb outcome, and safety for NOAC over warfarin persisted in four NOAC subgroups ( $P$ interaction all >0.05) and in high risk subgroups. Third, NOAC reduced MACE more in diabetic AF patients with a high atherosclerotic burden including the elderly, and the presence of IHD or PAD.

\section{Comparisons of four NOACs vs. warfarin in diabetic AF population}


The meta-analysis of the four landmark NOAC trials indicated that NOACs significantly reduced the composite efficacy endpoint when compared to warfarin both in non-valvular AF patients with diabetes and in those without diabetes, with no significant interaction by diabetes status and treatment.[16-18] In a post hoc analysis of ARISTOTLE trial, a significant interaction was noted between diabetes status and treatment regarding the risk of major bleeding $(P$ interaction $=0.0034)$, suggesting that apixaban reduces more major bleeding than warfarin only among AF patients without diabetes.[7] A post hoc analysis of the RE-LY trial showed a comparable risk of major bleeding in AF patients with diabetes treated with dabigatran $110 \mathrm{mg}$ twice daily vs. warfarin (HR: 0.91; $95 \% \mathrm{Cl}$ : [0.70-1.19]), which was in contrast to a significantly lower risk of major bleeding (HR: 0.76; 95\% Cl: [0.64-0.90]) in non-diabetic patients treated with dabigatran $100 \mathrm{mg}$ twice daily vs. warfarin.[6] In the post hoc analysis of ROCKET-AF study, rivaroxaban showed a comparable risk of major bleeding to warfarin either in the diabetic or non-diabetic subgroup, and there was no significant interaction between diabetic status and the risk of bleeding.[19] Finally, in the post hoc analysis of ENGAGEAF TIMI 48 trial, edoxaban had a significantly lower risk of major bleeding than warfarin both in the diabetic (HR: 0.78; 95\% Cl: [0.63-0.95]) and non-diabetic subgroups (HR: 0.81; 95\% Cl: [0.69-0.95]) (P interaction > 0.10). $[17,18]$ In summary, the advantage of NOACs over warfarin in efficacy generally persisted in diabetic subgroup treated with four NAOCs, whereas the advantage of safety profiles for NOACs over warfarin had some conflicting results in diabetic AF population treated with NOACs, especially in case of apixaban and dabigatran $110 \mathrm{mg}$.

The present study indicated that NOACs was associated with a significantly lower MACE than warfarin in those diabetic AF population with a high atherosclerotic burden like the presence of concomitant IHD or PAD

(Fig. 4). For AF patient comorbid with IHD or PAD, guidelines recommend the use of oral anticoagulant (OAC) rather than APT.[4, 5] However, there are no data or guideline recommendations specifically focused on the optimal treatment for diabetic AF patients with concomitant IHD or PAD.[5, 20, 21] Previous studies indicated that warfarin may increase vascular calcification via inhibition of the activation of matrix G1a protein, and had been reported to increase coronary or peripheral vascular calcification, potentially influencing symptoms and outcomes in patients with IHD or PAD.[22-26] Furthermore, patients with IHD or PAD have a higher risk of bleeding events compared to those without IHD or PAD, and the bleeding events may further increase the risk of ischemic events in the IHD or PAD, for example, discontinuation of OAC due to bleeding may cause consequent ischemic event like AMI or critical limb ischemia.[27] Our present study demonstrates the benefit of NOACs over warfarin regarding to the effectiveness and safety outcomes even in a very high risk patient population comorbid with AF, diabetes, and IHD/PAD.

\section{Major limb outcomes for NOACs vs. warfarin in diabetic AF population}

Data regarding to the major adverse limb events for AF patients treated with NOAC vs. warfarin are limited. We are only aware of one retrospective study investigating the major limb outcomes for diabetic AF patients treated with NOAC vs. warfarin.[28] Baker et al. studied 10,700 and 13,946 diabetic AF patients treated with rivaroxaban and warfarin, respectively, by using a claims database in USA, whereby rivaroxaban was associated with a $25 \%$ reduced risk of MACE and a $63 \%$ reduced risk of MALE compared to warfarin, with no difference in major bleeding.[28] Our present study shows that NOACs, with nearly $50 \%$ of whom treated with 
rivaroxaban, were also associated with a significantly lower risk of MALE than warfarin in diabetic AF patients. Although there is no difference for the advantage on MALE for different NOACs over warfarin ( $P$ interaction $=0.81$ within four NOACs), the other three NOACs except for rivaroxaban showed non-significantly lower risk of MALE than warfarin among the diabetic patients, possibly due to a smaller sample size of other three NOACs when compared to rivaroxaban (Fig. 3).

Recently, the COMPASS trial showed a strategy of combined therapy with aspirin and rivaroxaban $(2.5 \mathrm{mg}$ twice per day) or rivaroxaban alone ( $5 \mathrm{mg}$ twice per day) was associated with a significantly lower risk of major adverse limb events than aspirin alone in 27,000 patients with stable atherosclerotic vascular disease, nearly $45 \%$ of whom had comorbid diabetes.[9] Although the COMPASS trial differ from our present study in that it did not enroll AF patients, used a lower dose of rivaroxaban, and used aspirin but not warfarin as a comparator, the COMPASS trial firstly demonstrated that anticoagulant regimen with rivaroxaban indeed provide an extra benefit in improving MALE outcome in patients with a high atherosclerotic burden when compared to the current standard treatment. Until now, there are no large randomized controlled studies evaluating the major limb outcome for AF patients with a high atherosclerotic burden or AF treated with other three NOACs.

\section{Limitations}

The present study has several limitations. First, our study is a retrospective cohort study. Although the use of inverse propensity score weighting with adjustment of several variables allowed the balance of baseline comorbidities among the study groups, selection bias and residual confounding by unobserved or unmeasured variables could not be excluded in the present study. Second, misclassification and miscoding of the baseline comorbidities and study outcomes is a potential limitation. Third, laboratory data such as international normalized ratio (INR) for patients treated with warfarin were not obtained in the NHIRD database; indeed, Asian populations treated with warfarin had a substantially lower time in therapeutic range (TTR) of INR target in range of 2.0 to 3.0 than regions of the world.[29] Therefore, the superiority of NOACs over warfarin may be partly due to low TTR for those patients treated with warfarin in the present study.[30] Fourth, renal function for each patient are lacking for the NHIRD, and renal dysfunction may interfere with the decision regarding the choices or drug dosages for each patient. Finally, glycated hemoglobin is directly associated with risk of stroke in diabetic patients with AF[31]; however, we are unable to determine the quality of glycemic control for each diabetic AF patient due to lack of glycated hemoglobin data.

\section{Conclusions}

NOACs were associated with a lower risk of effectiveness, safety, and major adverse limb events than warfarin among diabetic AF patients. Thromboprophylaxis with NOACs should be considered in the diabetic AF population with a high atherosclerotic burden.

\section{Abbreviations}

$\mathrm{AF}=$ atrial fibrillation 
AMI = acute myocardial infarction

APT = antiplatelet agent

$\mathrm{CHA}_{2} \mathrm{DS}_{2}$-VASc = congestive heart failure, hypertension, age 75 years or older, diabetes mellitus, previous stroke/transient ischemic attack, vascular disease, age 65 to 74 years, female

CKD = chronic kidney disease;

$\mathbf{D M}=$ diabetes mellitus

HAS-BLED = hypertension, abnormal renal or liver function, stroke, bleeding history, labile INR, age 65 years or older, and antiplatelet drug or alcohol use

$\mathrm{ICH}=$ intracranial hemorrhage

IHD = ischemic heart disease

IS/SE = ischemic stroke/systemic embolism

MACE = major adverse cardiovascular event

MALE = major adverse limb event

NOAC $=$ non-vitamin $\mathrm{K}$ antagonist oral anticoagulants

$\mathrm{PAD}=$ peripheral artery disease

PSSW = propensity score stabilized weighting

\section{Declarations}

\section{Ethics approval and consent to participate}

The study protocol complies with the Declaration of Helsinki and was approved by the Institutional Review Board of the Chang Gung Medical Foundation.

\section{Disclosures}

None directly related to this paper.

GYHL: Consultant for Bayer/Janssen, BMS/Pfizer, Medtronic, Boehringer Ingelheim, Novartis, Verseon and Daiichi-Sankyo. Speaker for Bayer, BMS/Pfizer, Medtronic, Boehringer Ingelheim, and Daiichi-Sankyo. No fees are directly received personally. The remaining authors have nothing to disclose. 


\section{Consent for publications}

Not applicable

\section{Availability of data and materials}

The datasets used in this study were only available in the Health and Welfare Data Center, Taiwan. The SAS programs (codes) involved for this study are available from the corresponding author on reasonable request.

\section{Competing interests}

The authors declare that they have no competing interests.

\section{Funding}

This study was supported by grants 108-2314-B-182-053-MY2 from the Ministry of Science and Technology and grants CMRPG3J1371, CMRPD1K0031, CMRPG3K0021 and CORPG3G0351 from Chang Gung Memorial Hospital, Linkou, Taiwan.

\section{Author's contributions}

YHC, HFL, and TFC contributed to conception and design of the study, analysis and interpretation of the data, wrote the manuscript and approved submission. PRL, JRL, and LCS contributed data acquisition and analysis. YHC and LCS contributed to analysis of data and provided critical revision of the paper. LSW, SHC, YHY, CTK, LCS, and GYHL contributed to conception/design, and provided critical revision of the paper for the important intellectual content. All authors read and approved the final manuscript.

\section{Acknowledgements}

This study is based in part on National Health Insurance Research Database provided by the Applied Health Research Data Integration Service from National Health Insurance Administration, Taiwan. The interpretation and conclusions contained herein do not represent those of the National Health Insurance Administration, Ministry of Health and Welfare or National Health Research Institutes.

\section{References}


1. Kirchhof P, Benussi S, Kotecha D, Ahlsson A, Atar D, Casadei B, Castella M, Diener HC, Heidbuchel H, Hendriks J et al: 2016 ESC Guidelines for the management of atrial fibrillation developed in collaboration with EACTS. Eur Heart J 2016, 37(38):2893-2962.

2. Peters SA, Huxley RR, Woodward M: Diabetes as a risk factor for stroke in women compared with men: a systematic review and meta-analysis of 64 cohorts, including 775,385 individuals and 12,539 strokes. Lancet 2014, 383(9933):1973-1980.

3. Friberg L, Rosenqvist M, Lip GY: Evaluation of risk stratification schemes for ischaemic stroke and bleeding in 182678 patients with atrial fibrillation: the Swedish Atrial Fibrillation cohort study. Eur Heart J 2012, 33(12):1500-1510.

4. Steffel J, Verhamme P, Potpara TS, Albaladejo P, Antz M, Desteghe L, Haeusler KG, Oldgren J, Reinecke H, Roldan-Schilling V et al: The 2018 European Heart Rhythm Association Practical Guide on the use of non-vitamin K antagonist oral anticoagulants in patients with atrial fibrillation. Eur Heart $\mathrm{J} 2018$, 39(16):1330-1393.

5. Lip GYH, Banerjee A, Boriani G, Chiang CE, Fargo R, Freedman B, Lane DA, Ruff CT, Turakhia M, Werring $\mathrm{D}$ et al: Antithrombotic Therapy for Atrial Fibrillation: CHEST Guideline and Expert Panel Report. Chest 2018, 154(5):1121-1201.

6. Brambatti M, Darius H, Oldgren J, Clemens A, Noack HH, Brueckmann M, Yusuf S, Wallentin L, Ezekowitz MD, Connolly SJ et al: Comparison of dabigatran versus warfarin in diabetic patients with atrial fibrillation: Results from the RE-LY trial. Int J Cardiol 2015, 196:127-131.

7. Ezekowitz JA, Lewis BS, Lopes RD, Wojdyla DM, McMurray JJ, Hanna M, Atar D, Cecilia Bahit M, Keltai M, Lopez-Sendon JL et al: Clinical outcomes of patients with diabetes and atrial fibrillation treated with apixaban: results from the ARISTOTLE trial. Eur Heart J Cardiovasc Pharmacother 2015, 1(2):86-94.

8. Eikelboom JW, Connolly SJ, Bosch J, Dagenais GR, Hart RG, Shestakovska O, Diaz R, Alings M, Lonn EM, Anand SS et al: Rivaroxaban with or without Aspirin in Stable Cardiovascular Disease. N Engl J Med 2017, 377(14):1319-1330.

9. Anand SS, Bosch J, Eikelboom JW, Connolly SJ, Diaz R, Widimsky P, Aboyans V, Alings M, Kakkar AK, Keltai $\mathrm{K}$ et al: Rivaroxaban with or without aspirin in patients with stable peripheral or carotid artery disease: an international, randomised, double-blind, placebo-controlled trial. Lancet 2018, 391(10117):219-229.

10. National Health Insurance Administration, Ministry of Health and Welfare, Taiwan. National Health Insurance Annual Statistical Report 2018 [updated Dec. 2, 2019. Available from: https://www.nhi.gov.tw/English/Content_List.aspx? $\mathrm{n}=\mathrm{AB} 41 \mathrm{~B} 66610 \mathrm{EAC01A} \&$ topn=616B97F8DF2C3614.

11. Pamukcu B, Lip GY, Lane DA: Simplifying stroke risk stratification in atrial fibrillation patients: implications of the CHA2DS2-VASc risk stratification scores. Age Ageing 2010, 39(5):533-535.

12. Pisters R, Lane DA, Nieuwlaat R, de Vos CB, Crijns HJ, Lip GY: A novel user-friendly score (HAS-BLED) to assess 1-year risk of major bleeding in patients with atrial fibrillation: the Euro Heart Survey. Chest 2010, 138(5):1093-1100. 
13. Xu S, Ross C, Raebel MA, Shetterly S, Blanchette C, Smith D: Use of stabilized inverse propensity scores as weights to directly estimate relative risk and its confidence intervals. Value Health 2010, 13(2):273277.

14. McCaffrey DF, Griffin BA, Almirall D, Slaughter ME, Ramchand R, Burgette LF: A tutorial on propensity score estimation for multiple treatments using generalized boosted models. Stat Med 2013, 32(19):3388-3414.

15. Austin PC: Balance diagnostics for comparing the distribution of baseline covariates between treatment groups in propensity-score matched samples. Stat Med 2009, 28(25):3083-3107.

16. Plitt A, McGuire DK, Giugliano RP: Atrial Fibrillation, Type 2 Diabetes, and Non-Vitamin K Antagonist Oral Anticoagulants: A Review. JAMA Cardiol 2017, 2(4):442-448.

17. Itzhaki Ben Zadok 0 , Eisen A: Use of non-vitamin K oral anticoagulants in people with atrial fibrillation and diabetes mellitus. Diabet Med 2018, 35(5):548-556.

18. Patti G, Di Gioia G, Cavallari I, Nenna A: Safety and efficacy of nonvitamin K antagonist oral anticoagulants versus warfarin in diabetic patients with atrial fibrillation: A study-level meta-analysis of phase III randomized trials. Diabetes Metab Res Rev 2017, 33(3).

19. Bansilal S, Bloomgarden Z, Halperin JL, Hellkamp AS, Lokhnygina Y, Patel MR, Becker RC, Breithardt G, Hacke W, Hankey GJ et al: Efficacy and safety of rivaroxaban in patients with diabetes and nonvalvular atrial fibrillation: the Rivaroxaban Once-daily, Oral, Direct Factor Xa Inhibition Compared with Vitamin K Antagonism for Prevention of Stroke and Embolism Trial in Atrial Fibrillation (ROCKET AF Trial). Am Heart J 2015, 170(4):675-682 e678.

20. Aboyans V, Ricco JB, Bartelink MEL, Bjorck M, Brodmann M, Cohnert T, Collet JP, Czerny M, De Carlo M, Debus S et al: 2017 ESC Guidelines on the Diagnosis and Treatment of Peripheral Arterial Diseases, in collaboration with the European Society for Vascular Surgery (ESVS): Document covering atherosclerotic disease of extracranial carotid and vertebral, mesenteric, renal, upper and lower extremity arteriesEndorsed by: the European Stroke Organization (ESO)The Task Force for the Diagnosis and Treatment of Peripheral Arterial Diseases of the European Society of Cardiology (ESC) and of the European Society for Vascular Surgery (ESVS). Eur Heart J 2018, 39(9):763-816.

21. Andrade JG, Verma A, Mitchell LB, Parkash R, Leblanc K, Atzema C, Healey JS, Bell A, Cairns J, Connolly S et al: 2018 Focused Update of the Canadian Cardiovascular Society Guidelines for the Management of Atrial Fibrillation. Can J Cardiol 2018, 34(11):1371-1392.

22. Han KH, O'Neill WC: Increased Peripheral Arterial Calcification in Patients Receiving Warfarin. J Am Heart Assoc 2016, 5(1).

23. Lomashvili KA, Wang X, Wallin R, O'Neill WC: Matrix Gla protein metabolism in vascular smooth muscle and role in uremic vascular calcification. J Biol Chem 2011, 286(33):28715-28722.

24. Andrews J, Psaltis PJ, Bayturan O, Shao M, Stegman B, Elshazly M, Kapadia SR, Tuzcu EM, Nissen SE, Nicholls SJ et al: Warfarin Use Is Associated With Progressive Coronary Arterial Calcification: Insights From Serial Intravascular Ultrasound. JACC Cardiovasc Imaging 2018, 11(9):1315-1323.

25. Guzman RJ, Brinkley DM, Schumacher PM, Donahue RM, Beavers H, Qin X: Tibial artery calcification as a marker of amputation risk in patients with peripheral arterial disease. J Am Coll Cardiol2008, 
51(20):1967-1974.

26. Zettervall SL, Marshall AP, Fleser P, Guzman RJ: Association of arterial calcification with chronic limb ischemia in patients with peripheral artery disease. J Vasc Surg 2018, 67(2):507-513.

27. van Hattum ES, Algra A, Lawson JA, Eikelboom BC, Moll FL, Tangelder MJ: Bleeding increases the risk of ischemic events in patients with peripheral arterial disease. Circulation 2009, 120(16):1569-1576.

28. Baker WL, Beyer-Westendorf J, Bunz TJ, Eriksson D, Meinecke AK, Sood NA, Coleman Cl: Effectiveness and safety of rivaroxaban and warfarin for prevention of major adverse cardiovascular or limb events in patients with non-valvular atrial fibrillation and type 2 diabetes. Diabetes Obes Metab 2019, 21(9):21072114.

29. Oh S, Goto S, Accetta G, Angchaisuksiri P, Camm AJ, Cools F, Haas S, Kayani G, Koretsune Y, Lim TW et al: Vitamin $\mathrm{K}$ antagonist control in patients with atrial fibrillation in Asia compared with other regions of the world: Real-world data from the GARFIELD-AF registry. Int J Cardiol 2016, 223:543-547.

30. Wang KL, Lip GY, Lin SJ, Chiang CE: Non-Vitamin K Antagonist Oral Anticoagulants for Stroke Prevention in Asian Patients With Nonvalvular Atrial Fibrillation: Meta-Analysis. Stroke 2015, 46(9):25552561.

31. Saliba W, Barnett-Griness O, Elias M, Rennert G: Glycated hemoglobin and risk of first episode stroke in diabetic patients with atrial fibrillation: A cohort study. Heart Rhythm 2015, 12(5):886-892.

\section{Tables}

Table 1

Baseline characteristics of non-valvular atrial fibrillation (AF) patients with diabetes mellitus (DM) before propensity score-based stabilized weights 


\begin{tabular}{|c|c|c|c|c|c|c|c|}
\hline & $\begin{array}{l}\text { Apixaban } \\
\mathrm{n}=3,249\end{array}$ & $\begin{array}{r}\mathrm{NC} \\
\begin{array}{c}\text { Dabigatran } \\
\mathrm{n}=6,531\end{array}\end{array}$ & $\begin{array}{l}\text { Edoxaban } \\
\mathrm{n}=1,389\end{array}$ & $\begin{array}{c}\text { Rivaroxaban } \\
\mathrm{n}=9,798\end{array}$ & $\begin{array}{c}\text { NOACs } \\
(\mathrm{A}+\mathrm{D}+\mathrm{R}+\mathrm{E}) \\
(\mathrm{n}=20,967) \\
\end{array}$ & \begin{tabular}{|c|} 
Warfarin \\
$(\mathrm{n}$ \\
$=5,812)$
\end{tabular} & $\begin{array}{c}\text { NOACs } \\
\text { vs. } \\
\text { Warfarin }\end{array}$ \\
\hline \multicolumn{8}{|l|}{ Age } \\
\hline $\begin{array}{l}\text { (mean } \pm \\
\text { STD) }\end{array}$ & $76 \pm 9.7$ & $74 \pm 9.7$ & $75.4 \pm 9.7$ & $75.5 \pm 9.7$ & $75.1 \pm 9.8$ & $72.5 \pm 11.6$ & 0.2406 \\
\hline$<65$ & $\begin{array}{c}428 \\
(13.2 \%)\end{array}$ & $\begin{array}{c}1114 \\
(17.1 \%)\end{array}$ & $\begin{array}{c}196 \\
(14.1 \%)\end{array}$ & $\begin{array}{c}1345 \\
(13.7 \%)\end{array}$ & $\begin{array}{c}3083 \\
(14.7 \%)\end{array}$ & $\begin{array}{c}1664 \\
(28.6 \%)\end{array}$ & 0.3470 \\
\hline $65-74$ & $\begin{array}{c}976 \\
(30 \%)\end{array}$ & $\begin{array}{c}2229 \\
(34.1 \%)\end{array}$ & $\begin{array}{c}427 \\
(30.7 \%)\end{array}$ & $3033(31 \%)$ & $\begin{array}{c}6665 \\
(31.8 \%)\end{array}$ & $\begin{array}{c}1446 \\
(24.9 \%)\end{array}$ & \\
\hline $75-84$ & $\begin{array}{c}1210 \\
(37.2 \%)\end{array}$ & $\begin{array}{l}2354 \\
(36 \%)\end{array}$ & $\begin{array}{c}539 \\
(38.8 \%)\end{array}$ & $\begin{array}{c}3766 \\
(38.4 \%)\end{array}$ & $\begin{array}{c}7869 \\
(37.5 \%)\end{array}$ & $\begin{array}{c}1848 \\
(31.8 \%)\end{array}$ & \\
\hline$>85$ & $\begin{array}{c}635 \\
(19.5 \%) \\
\end{array}$ & $\begin{array}{c}834 \\
(12.8 \%) \\
\end{array}$ & $\begin{array}{c}227 \\
(16.3 \%)\end{array}$ & $\begin{array}{c}1654 \\
(16.9 \%)\end{array}$ & $3350(16 \%)$ & $\begin{array}{c}854 \\
(14.7 \%)\end{array}$ & \\
\hline Male & $\begin{array}{c}1704 \\
(52.5 \%)\end{array}$ & $\begin{array}{c}3800 \\
(58.2 \%)\end{array}$ & $\begin{array}{c}756 \\
(54.4 \%)\end{array}$ & $\begin{array}{c}5045 \\
(51.5 \%)\end{array}$ & $\begin{array}{c}11305 \\
(53.9 \%)\end{array}$ & $\begin{array}{c}3080 \\
(53 \%)\end{array}$ & 0.0185 \\
\hline $\begin{array}{l}\mathrm{CHA}_{2} \mathrm{DS}_{2^{-}} \\
\text {VASc (mean } \\
\pm \text { STD) }\end{array}$ & $4.7 \pm 1.6$ & $4.4 \pm 1.6$ & $4.5 \pm 1.5$ & $4.6 \pm 1.6$ & $4.5 \pm 1.6$ & $4.2 \pm 1.8$ & 0.1890 \\
\hline $\begin{array}{l}\text { HAS-BLED } \\
\text { (mean } \pm \\
\text { STD) }\end{array}$ & $3.2 \pm 1$ & $3 \pm 1$ & $3.2 \pm 1.1$ & $3.1 \pm 1$ & $3.1 \pm 1$ & $2.9 \pm 1.2$ & 0.2299 \\
\hline Hypertension & $\begin{array}{l}2697 \\
(83 \%) \\
\end{array}$ & $\begin{array}{c}5206 \\
(79.7 \%) \\
\end{array}$ & $\begin{array}{c}1164 \\
(83.8 \%) \\
\end{array}$ & $\begin{array}{c}7922 \\
(80.9 \%) \\
\end{array}$ & $\begin{array}{l}16989 \\
(81 \%)\end{array}$ & $\begin{array}{c}4446 \\
(76.5 \%)\end{array}$ & 0.1109 \\
\hline Dyslipidemia & $\begin{array}{c}2200 \\
(67.7 \%)\end{array}$ & $\begin{array}{c}4102 \\
(62.8 \%)\end{array}$ & $\begin{array}{c}1011 \\
(72.8 \%)\end{array}$ & $\begin{array}{c}6425 \\
(65.6 \%)\end{array}$ & $\begin{array}{l}13738 \\
(65.5 \%)\end{array}$ & $\begin{array}{c}3409 \\
(58.7 \%)\end{array}$ & 0.1419 \\
\hline $\begin{array}{l}\text { Chronic live } \\
\text { disease }\end{array}$ & $\begin{array}{c}455 \\
(14 \%) \\
\end{array}$ & $\begin{array}{c}834 \\
(12.8 \%) \\
\end{array}$ & $\begin{array}{c}219 \\
(15.8 \%) \\
\end{array}$ & $\begin{array}{c}1345 \\
(13.7 \%) \\
\end{array}$ & $\begin{array}{c}2853 \\
(13.6 \%) \\
\end{array}$ & $\begin{array}{c}779 \\
(13.4 \%) \\
\end{array}$ & 0.0060 \\
\hline $\begin{array}{l}\text { Chronic } \\
\text { kidney } \\
\text { disease }\end{array}$ & $\begin{array}{c}880 \\
(27.1 \%)\end{array}$ & $\begin{array}{c}1164 \\
(17.8 \%)\end{array}$ & $\begin{array}{c}425 \\
(30.6 \%)\end{array}$ & $\begin{array}{c}2295 \\
(23.4 \%)\end{array}$ & $\begin{array}{c}4764 \\
(22.7 \%)\end{array}$ & $\begin{array}{c}1371 \\
(23.6 \%)\end{array}$ & 0.0206 \\
\hline \begin{tabular}{l|} 
Chronic lung \\
disease
\end{tabular} & $\begin{array}{c}413 \\
(12.7 \%)\end{array}$ & $\begin{array}{c}739 \\
(11.3 \%)\end{array}$ & $\begin{array}{c}165 \\
(11.9 \%)\end{array}$ & $\begin{array}{c}1389 \\
(14.2 \%)\end{array}$ & $\begin{array}{c}2706 \\
(12.9 \%)\end{array}$ & $\begin{array}{c}792 \\
(13.6 \%)\end{array}$ & 0.0213 \\
\hline Gout & $\begin{array}{c}719 \\
(22.1 \%)\end{array}$ & $\begin{array}{c}1166 \\
(17.9 \%)\end{array}$ & $\begin{array}{c}328 \\
(23.6 \%)\end{array}$ & $\begin{array}{c}1994 \\
(20.4 \%)\end{array}$ & $\begin{array}{c}4207 \\
(20.1 \%)\end{array}$ & $\begin{array}{c}1113 \\
(19.2 \%)\end{array}$ & 0.0230 \\
\hline $\begin{array}{l}\text { Congestive } \\
\text { heart failure }\end{array}$ & $\begin{array}{c}438 \\
(13.5 \%)\end{array}$ & $\begin{array}{c}684 \\
(10.5 \%)\end{array}$ & $\begin{array}{c}175 \\
(12.6 \%)\end{array}$ & $\begin{array}{c}1324 \\
(13.5 \%)\end{array}$ & $\begin{array}{c}2621 \\
(12.5 \%)\end{array}$ & $\begin{array}{c}919 \\
(15.8 \%)\end{array}$ & 0.0951 \\
\hline \begin{tabular}{l|} 
Chronic \\
ischemic \\
heart disease
\end{tabular} & $\begin{array}{c}498 \\
(15.3 \%)\end{array}$ & $\begin{array}{c}764 \\
(11.7 \%)\end{array}$ & $\begin{array}{c}210 \\
(15.1 \%)\end{array}$ & $\begin{array}{c}1437 \\
(14.7 \%)\end{array}$ & $\begin{array}{c}2909 \\
(13.9 \%)\end{array}$ & $\begin{array}{c}844 \\
(14.5 \%)\end{array}$ & 0.0186 \\
\hline $\begin{array}{l}\text { Peripheral } \\
\text { artery } \\
\text { disease }\end{array}$ & $\begin{array}{c}296 \\
(9.1 \%)\end{array}$ & 616 (9.4\%) & $\begin{array}{c}132 \\
(9.5 \%)\end{array}$ & $959(9.8 \%)$ & $2003(9.6 \%)$ & $\begin{array}{c}544 \\
(9.4 \%)\end{array}$ & 0.0066 \\
\hline Stroke & $\begin{array}{c}730 \\
(22.5 \%)\end{array}$ & $\begin{array}{c}1597 \\
(24.5 \%)\end{array}$ & $\begin{array}{c}205 \\
(14.8 \%)\end{array}$ & $\begin{array}{c}2259 \\
(23.1 \%)\end{array}$ & $\begin{array}{c}4791 \\
(22.9 \%)\end{array}$ & $\begin{array}{c}1034 \\
(17.8 \%)\end{array}$ & 0.1260 \\
\hline Malignancy & $\begin{array}{c}370 \\
(11.4 \%)\end{array}$ & $573(8.8 \%)$ & $\begin{array}{c}165 \\
(11.9 \%)\end{array}$ & $\begin{array}{c}1059 \\
(10.8 \%)\end{array}$ & $\begin{array}{c}2167 \\
(10.3 \%)\end{array}$ & $\begin{array}{c}574 \\
(9.9 \%)\end{array}$ & 0.0152 \\
\hline PCI & $\begin{array}{c}330 \\
(10.2 \%)\end{array}$ & $417(6.4 \%)$ & $\begin{array}{c}149 \\
(10.7 \%)\end{array}$ & $868(8.9 \%)$ & $1764(8.4 \%)$ & $\begin{array}{c}510 \\
(8.8 \%)\end{array}$ & 0.0129 \\
\hline CABG & $31(1 \%)$ & $25(0.4 \%)$ & $10(0.7 \%)$ & $71(0.7 \%)$ & $137(0.7 \%)$ & $90(1.6 \%)$ & 0.0859 \\
\hline $\begin{array}{l}\text { History of } \\
\text { bleeding }\end{array}$ & $\begin{array}{c}74 \\
(2.3 \%)\end{array}$ & $117(1.8 \%)$ & $24(1.7 \%)$ & $222(2.3 \%)$ & $437(2.1 \%)$ & $\begin{array}{c}148 \\
(2.6 \%) \\
\end{array}$ & 0.0307 \\
\hline $\begin{array}{l}\text { Use of } \\
\text { NSAIDs }\end{array}$ & $\begin{array}{c}918 \\
(28.3 \%)\end{array}$ & $\begin{array}{c}1551 \\
(23.8 \%)\end{array}$ & $\begin{array}{c}389 \\
(28 \%)\end{array}$ & $\begin{array}{c}2581 \\
(26.3 \%)\end{array}$ & $\begin{array}{c}5439 \\
(25.9 \%)\end{array}$ & $\begin{array}{c}1546 \\
(26.6 \%)\end{array}$ & 0.0150 \\
\hline Use of PPI & $\begin{array}{c}451 \\
(13.9 \%)\end{array}$ & $622(9.5 \%)$ & $\begin{array}{c}174 \\
(12.5 \%)\end{array}$ & $\begin{array}{c}1187 \\
(12.1 \%)\end{array}$ & $\begin{array}{c}2434 \\
(11.6 \%)\end{array}$ & $\begin{array}{c}887 \\
(15.3 \%)\end{array}$ & 0.1073 \\
\hline $\begin{array}{l}\text { Use of } \\
\mathrm{H}_{2} \text { blocker }\end{array}$ & $\begin{array}{c}1132 \\
(34.8 \%)\end{array}$ & $\begin{array}{c}2068 \\
(31.7 \%)\end{array}$ & $\begin{array}{c}463 \\
(33.3 \%)\end{array}$ & $\begin{array}{c}3201 \\
(32.7 \%)\end{array}$ & $\begin{array}{c}6864 \\
(32.7 \%)\end{array}$ & $\begin{array}{c}2069 \\
(35.6 \%)\end{array}$ & 0.0604 \\
\hline Use of & 2006 & 3781 & 795 & 5904 & 12486 & 3784 & 0.1148 \\
\hline
\end{tabular}




\begin{tabular}{|c|c|c|c|c|c|c|c|}
\hline antiplatelet & (61.7\%) & (57.9\%) & (57.2\%) & $(60.3 \%)$ & (59.6\%) & $(65.1 \%)$ & \\
\hline $\begin{array}{l}\text { Use of } \\
\text { ACEI/ARB }\end{array}$ & $\begin{array}{c}2205 \\
(67.9 \%) \\
\end{array}$ & $\begin{array}{c}4470 \\
(68.4 \%) \\
\end{array}$ & $\begin{array}{c}955 \\
(68.8 \%) \\
\end{array}$ & $\begin{array}{c}6731 \\
(68.7 \%) \\
\end{array}$ & $\begin{array}{c}14361 \\
(68.5 \%) \\
\end{array}$ & $\begin{array}{c}3984 \\
(68.6 \%)\end{array}$ & 0.0012 \\
\hline $\begin{array}{l}\text { Use of beta- } \\
\text { blocker }\end{array}$ & $\begin{array}{c}2031 \\
(62.5 \%)\end{array}$ & $\begin{array}{c}3769 \\
(57.7 \%)\end{array}$ & $\begin{array}{c}925 \\
(66.6 \%)\end{array}$ & $\begin{array}{c}5939 \\
(60.6 \%)\end{array}$ & $\begin{array}{l}12664 \\
(60.4 \%)\end{array}$ & $\begin{array}{c}3754 \\
(64.6 \%)\end{array}$ & 0.0866 \\
\hline $\begin{array}{l}\text { Use of } \\
\text { verapamil or } \\
\text { diltiazem }\end{array}$ & $\begin{array}{c}824 \\
(25.4 \%)\end{array}$ & $\begin{array}{l}1505 \\
(23 \%)\end{array}$ & $\begin{array}{c}260 \\
(18.7 \%)\end{array}$ & $2551(26 \%)$ & $\begin{array}{c}5140 \\
(24.5 \%)\end{array}$ & $\begin{array}{c}1666 \\
(28.7 \%)\end{array}$ & 0.0940 \\
\hline Use of statin & $\begin{array}{c}1600 \\
(49.3 \%)\end{array}$ & $\begin{array}{c}2907 \\
(44.5 \%)\end{array}$ & $\begin{array}{c}701 \\
(50.5 \%)\end{array}$ & $\begin{array}{c}4574 \\
(46.7 \%)\end{array}$ & $\begin{array}{c}9782 \\
(46.7 \%)\end{array}$ & $\begin{array}{c}2263 \\
(38.9 \%)\end{array}$ & 0.1564 \\
\hline Use of APT & $\begin{array}{c}480 \\
(14.8 \%)\end{array}$ & $\begin{array}{c}1383 \\
(21.2 \%)\end{array}$ & $\begin{array}{c}140 \\
(10.1 \%)\end{array}$ & $\begin{array}{c}1926 \\
(19.7 \%)\end{array}$ & $\begin{array}{c}3929 \\
(18.7 \%)\end{array}$ & $\begin{array}{c}2063 \\
(35.5 \%)\end{array}$ & 0.3838 \\
\hline $\begin{array}{l}\text { Use } \\
\text { metformin }\end{array}$ & $\begin{array}{c}1503 \\
(46.3 \%)\end{array}$ & $\begin{array}{c}3320 \\
(50.8 \%)\end{array}$ & $\begin{array}{c}584 \\
(42 \%)\end{array}$ & $\begin{array}{c}4488 \\
(45.8 \%)\end{array}$ & $\begin{array}{c}9895 \\
(47.2 \%) \\
\end{array}$ & $\begin{array}{c}2567 \\
(44.2 \%) \\
\end{array}$ & 0.0608 \\
\hline Use of SU & $\begin{array}{c}1214 \\
(37.4 \%)\end{array}$ & $\begin{array}{l}2675 \\
(41 \%)\end{array}$ & $\begin{array}{c}454 \\
(32.7 \%)\end{array}$ & $\begin{array}{c}3574 \\
(36.5 \%)\end{array}$ & $\begin{array}{c}7917 \\
(37.8 \%)\end{array}$ & $\begin{array}{c}2312 \\
(39.8 \%)\end{array}$ & 0.0415 \\
\hline $\begin{array}{l}\text { Use } \\
\text { glinide }\end{array}$ & $293(9 \%)$ & $498(7.6 \%)$ & 99 (7.1\%) & 846 (8.6\%) & $1736(8.3 \%)$ & $\begin{array}{c}714 \\
(12.3 \%) \\
\end{array}$ & 0.1321 \\
\hline $\begin{array}{l}\text { Use } \\
\text { acarbose }\end{array}$ & $\begin{array}{c}323 \\
(9.9 \%) \\
\end{array}$ & $654(10 \%)$ & $111(8 \%)$ & $924(9.4 \%)$ & $2012(9.6 \%)$ & $\begin{array}{c}645 \\
(11.1 \%) \\
\end{array}$ & 0.0493 \\
\hline $\begin{array}{ll}\begin{array}{l}\text { Use } \\
\text { glitazone }\end{array} & \text { of } \\
\end{array}$ & $\begin{array}{c}185 \\
(5.7 \%)\end{array}$ & $381(5.8 \%)$ & $68(4.9 \%)$ & 463 (4.7\%) & $1097(5.2 \%)$ & $\begin{array}{c}320 \\
(5.5 \%)\end{array}$ & 0.0121 \\
\hline Use of insulin & $\begin{array}{c}927 \\
(28.5 \%)\end{array}$ & $\begin{array}{c}1388 \\
(21.3 \%)\end{array}$ & $\begin{array}{c}305 \\
(22 \%)\end{array}$ & $\begin{array}{c}2601 \\
(26.6 \%)\end{array}$ & $\begin{array}{c}5221 \\
(24.9 \%)\end{array}$ & $\begin{array}{c}2008 \\
(34.6 \%)\end{array}$ & 0.2123 \\
\hline \begin{tabular}{|l} 
Use \\
SGLT2i
\end{tabular} & $\begin{array}{c}63 \\
(1.9 \%) \\
\end{array}$ & $54(0.8 \%)$ & $48(3.5 \%)$ & $106(1.1 \%)$ & $271(1.3 \%)$ & $20(0.3 \%)$ & 0.1054 \\
\hline
\end{tabular}

ACEI $=$ angiotensin-converting-enzyme inhibitor; $\mathrm{AF}=$ atrial fibrillation; $\mathrm{APT}=$ antiplatelet agent; $\mathrm{ARB}=$ angiotensin II receptor antagonists; $\mathrm{CABG}=$ coronary artery bypass grafting; $\mathrm{CHA}_{2} \mathrm{DS}_{2}-\mathrm{VASc}=$ congestive heart failure, hypertension, age 75 years or older, diabetes mellitus, previous stroke/transient ischemic attack, vascular disease, age 65 to 74 years, female; $\mathrm{DM}=$ diabetes mellitus; HAS-BLED $=$ hypertension, abnormal renal or liver function, stroke, bleeding history, labile INR, age 65 years or older, and antiplatelet drug or alcohol use; INR = international normalized ratio ; NOAC $=$ non-vitamin $\mathrm{K}$ antagonist oral anticoagulant; NSAIDs $=$ non-steroidal anti-inflammatory drugs; PCI $=$ Percutaneous coronary intervention; SGLT2i $=$ sodium glucose co-transporters 2 inhibitor; STD = standard deviation; SU = Sulfonylurea

\section{Table 2}

Baseline characteristics of non-valvular AF patients with DM after propensity score-based stabilized weights 


\begin{tabular}{|c|c|c|c|c|c|c|c|}
\hline & \multicolumn{4}{|c|}{ NOACs } & \multirow{3}{*}{$\begin{array}{c}\text { NOACs } \\
(A+D+R+E) \\
(n=20,967)\end{array}$} & \multirow{3}{*}{$\begin{array}{c}\text { Warfarin } \\
(\mathrm{n}= \\
5,812)\end{array}$} & \multirow{3}{*}{$\begin{array}{c}\text { NOACs } \\
\text { vs. } \\
\text { Warfarin }\end{array}$} \\
\hline & Apixaban & Dabigatran & Edoxaban & Rivaroxaban & & & \\
\hline & $\begin{array}{c}n= \\
3,249\end{array}$ & $\mathrm{n}=6,531$ & $\mathrm{n}=1,389$ & $\mathrm{n}=9,798$ & & & \\
\hline \multirow[t]{7}{*}{ E } & $75.6 \pm 10$ & $73.5 \pm 10.1$ & $74.9 \pm 9.9$ & $75 \pm 10.1$ & $74.6 \pm 10.1$ & $74.5 \pm 10.3$ & 0.0118 \\
\hline & $\begin{array}{c}499.76 \\
(15.6 \%)\end{array}$ & $\begin{array}{l}1329.46 \\
(20.3 \%)\end{array}$ & $\begin{array}{c}226.27 \\
(16.8 \%)\end{array}$ & $\begin{array}{l}1619.19 \\
(16.5 \%)\end{array}$ & $\begin{array}{l}3674.69 \\
(17.6 \%)\end{array}$ & $\begin{array}{c}992.87 \\
(17.8 \%)\end{array}$ & 0.0129 \\
\hline & $\begin{array}{c}923.58 \\
(28.8 \%) \\
\end{array}$ & $\begin{array}{l}2109.08 \\
(32.3 \%)\end{array}$ & $\begin{array}{c}396.11 \\
(29.4 \%)\end{array}$ & $\begin{array}{r}2894.27 \\
(29.5 \%) \\
\end{array}$ & $\begin{array}{l}6323.04 \\
(30.3 \%)\end{array}$ & $\begin{array}{l}1658.22 \\
(29.8 \%)\end{array}$ & \\
\hline & \begin{tabular}{|l|}
1163.61 \\
$(36.3 \%)$
\end{tabular} & $\begin{array}{l}2278.34 \\
(34.9 \%)\end{array}$ & $\begin{array}{l}506.75 \\
(37.7 \%)\end{array}$ & $\begin{array}{l}3656.43 \\
(37.3 \%)\end{array}$ & $\begin{array}{l}7605.13 \\
(36.4 \%)\end{array}$ & $\begin{array}{l}2030.02 \\
(36.4 \%)\end{array}$ & \\
\hline & $\begin{array}{c}620.66 \\
(19.4 \%)\end{array}$ & $\begin{array}{c}818.07 \\
(12.5 \%)\end{array}$ & $\begin{array}{c}216.63 \\
(16.1 \%)\end{array}$ & $\begin{array}{l}1627.86 \\
(16.6 \%)\end{array}$ & $\begin{array}{l}3283.22 \\
(15.7 \%)\end{array}$ & 891.61 & \\
\hline & $\begin{array}{c}1673.4 \\
(52.2 \%)\end{array}$ & $\begin{array}{c}3788.91 \\
(58 \%)\end{array}$ & $\begin{array}{c}730.05 \\
(54.3 \%)\end{array}$ & $\begin{array}{l}5027.21 \\
(51.3 \%)\end{array}$ & $\begin{array}{c}11219.58 \\
(53.7 \%)\end{array}$ & $\begin{array}{l}2981.44 \\
(53.5 \%)\end{array}$ & 0.0044 \\
\hline & $4.6 \pm 1.6$ & $4.3 \pm 1.6$ & $4.4 \pm 1.5$ & $4.5 \pm 1.7$ & $4.5 \pm 1.6$ & $4.4 \pm 1.6$ & 0.0184 \\
\hline & & & & & & & \\
\hline J & $3.2 \pm 1.1$ & $3 \pm 1.1$ & $3.1 \pm 1.1$ & $3.1 \pm 1.1$ & $3.1 \pm 1.1$ & $3 \pm 1.1$ & 0.0491 \\
\hline ion & \begin{tabular}{|c|}
2646.3 \\
$(82.5 \%)$
\end{tabular} & $\begin{array}{l}5147.03 \\
(78.8 \%)\end{array}$ & $\begin{array}{c}1117.08 \\
(83 \%)\end{array}$ & $\begin{array}{l}7823.89 \\
(79.9 \%)\end{array}$ & $\begin{array}{c}16734.29 \\
(80.1 \%)\end{array}$ & $\begin{array}{l}4438.09 \\
(79.6 \%)\end{array}$ & 0.0122 \\
\hline aia & \begin{tabular}{|l|}
2131.33 \\
$(66.5 \%)$
\end{tabular} & $\begin{array}{l}4013.75 \\
(61.4 \%) \\
\end{array}$ & $\begin{array}{c}964.54 \\
(71.7 \%)\end{array}$ & $\begin{array}{c}6272.89 \\
(64 \%)\end{array}$ & $\begin{array}{c}13382.51 \\
(64.1 \%)\end{array}$ & $\begin{array}{l}3545.77 \\
(63.6 \%)\end{array}$ & 0.0094 \\
\hline \multirow[t]{2}{*}{$\overline{\mathrm{ve}}$} & $\begin{array}{c}448.27 \\
(14 \%)\end{array}$ & $\begin{array}{c}836.45 \\
(12.8 \%)\end{array}$ & $\begin{array}{c}211.38 \\
(15.7 \%)\end{array}$ & $\begin{array}{l}1335.81 \\
(13.6 \%)\end{array}$ & $\begin{array}{l}2831.92 \\
(13.6 \%)\end{array}$ & $\begin{array}{c}745.06 \\
(13.4 \%)\end{array}$ & 0.0056 \\
\hline & $\begin{array}{l}884.71 \\
(27.6 \%)\end{array}$ & $\begin{array}{l}1165.76 \\
(17.8 \%)\end{array}$ & $\begin{array}{l}411.07 \\
(30.6 \%)\end{array}$ & $\begin{array}{l}2318.11 \\
(23.7 \%)\end{array}$ & $\begin{array}{l}4779.66 \\
(22.9 \%)\end{array}$ & $\begin{array}{l}1290.66 \\
(23.2 \%)\end{array}$ & 0.0066 \\
\hline \multirow[t]{2}{*}{ ng } & $\begin{array}{c}415.03 \\
(12.9 \%) \\
\end{array}$ & $\begin{array}{c}751.11 \\
(11.5 \%) \\
\end{array}$ & $\begin{array}{l}161.41 \\
(12 \%)\end{array}$ & $\begin{array}{l}1403.16 \\
(14.3 \%)\end{array}$ & $\begin{array}{c}2730.7 \\
(13.1 \%)\end{array}$ & $\begin{array}{c}747.12 \\
(13.4 \%)\end{array}$ & 0.0099 \\
\hline & $\begin{array}{c}706.18 \\
(22 \%) \\
\end{array}$ & $\begin{array}{c}1152.6 \\
(17.6 \%)\end{array}$ & $\begin{array}{c}317.42 \\
(23.6 \%)\end{array}$ & $\begin{array}{l}1975.72 \\
(20.2 \%)\end{array}$ & $\begin{array}{l}4151.94 \\
(19.9 \%)\end{array}$ & $\begin{array}{l}1105.89 \\
(19.8 \%)\end{array}$ & 0.0009 \\
\hline \multirow{2}{*}{ re } & $\begin{array}{c}461.45 \\
(14.4 \%)\end{array}$ & $\begin{array}{c}721.17 \\
(11 \%)\end{array}$ & $\begin{array}{c}174.76 \\
(13 \%)\end{array}$ & $\begin{array}{l}1401.59 \\
(14.3 \%)\end{array}$ & $\begin{array}{l}2758.96 \\
(13.2 \%)\end{array}$ & $\begin{array}{c}770.92 \\
(13.8 \%)\end{array}$ & 0.0185 \\
\hline & $\begin{array}{c}490.98 \\
(15.3 \%)\end{array}$ & $\begin{array}{c}764.79 \\
(11.7 \%)\end{array}$ & $\begin{array}{l}206.47 \\
(15.3 \%)\end{array}$ & $\begin{array}{l}1457.45 \\
(14.9 \%)\end{array}$ & $\begin{array}{c}2919.68 \\
(14 \%)\end{array}$ & $\begin{array}{c}740.87 \\
(13.3 \%)\end{array}$ & 0.0202 \\
\hline \multirow[t]{2}{*}{ 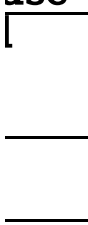 } & $\begin{array}{l}294.56 \\
(9.2 \%)\end{array}$ & $\begin{array}{l}615.97 \\
(9.4 \%)\end{array}$ & $\begin{array}{l}126.94 \\
(9.4 \%)\end{array}$ & $\begin{array}{l}961.97 \\
(9.8 \%)\end{array}$ & $\begin{array}{c}1999.44 \\
(9.6 \%)\end{array}$ & $\begin{array}{l}531.89 \\
(9.5 \%)\end{array}$ & 0.0010 \\
\hline & $\begin{array}{c}693.74 \\
(21.6 \%) \\
\end{array}$ & $\begin{array}{c}1497.7 \\
(22.9 \%) \\
\end{array}$ & $\begin{array}{c}189.25 \\
(14.1 \%)\end{array}$ & $\begin{array}{l}2161.77 \\
(22.1 \%) \\
\end{array}$ & $\begin{array}{l}4542.45 \\
(21.8 \%) \\
\end{array}$ & $\begin{array}{c}1175.9 \\
(21.1 \%) \\
\end{array}$ & 0.0160 \\
\hline \multirow[t]{7}{*}{ :y } & $\begin{array}{c}365.73 \\
(11.4 \%)\end{array}$ & $\begin{array}{l}562.12 \\
(8.6 \%)\end{array}$ & $\begin{array}{c}160.26 \\
(11.9 \%)\end{array}$ & $\begin{array}{l}1055.43 \\
(10.8 \%)\end{array}$ & $\begin{array}{l}2143.54 \\
(10.3 \%)\end{array}$ & $\begin{array}{c}578.15 \\
(10.4 \%)\end{array}$ & 0.0037 \\
\hline & $\begin{array}{c}324.92 \\
(10.1 \%)\end{array}$ & $\begin{array}{l}414.45 \\
(6.3 \%)\end{array}$ & $\begin{array}{c}143.9 \\
(10.7 \%)\end{array}$ & $\begin{array}{l}889.57 \\
(9.1 \%)\end{array}$ & $\begin{array}{c}1772.84 \\
(8.5 \%)\end{array}$ & $\begin{array}{l}459.64 \\
(8.3 \%)\end{array}$ & 0.0088 \\
\hline & $\begin{array}{l}35.34 \\
(1.1 \%)\end{array}$ & $\begin{array}{c}30.41 \\
(0.5 \%)\end{array}$ & $\begin{array}{l}10.85 \\
(0.8 \%)\end{array}$ & $\begin{array}{c}90.42 \\
(0.9 \%)\end{array}$ & $\begin{array}{l}167.02 \\
(0.8 \%)\end{array}$ & $\begin{array}{c}44.51 \\
(0.8 \%)\end{array}$ & 0.0001 \\
\hline & $\begin{array}{r}77.02 \\
(2.4 \%) \\
\end{array}$ & $\begin{array}{l}118.84 \\
(1.8 \%)\end{array}$ & $\begin{array}{l}24.55 \\
(1.8 \%) \\
\end{array}$ & $\begin{array}{l}229.26 \\
(2.3 \%) \\
\end{array}$ & $\begin{array}{l}449.66 \\
(2.2 \%) \\
\end{array}$ & $\begin{array}{l}119.51 \\
(2.1 \%)\end{array}$ & 0.0006 \\
\hline & $\begin{array}{c}908.1 \\
(28.3 \%)\end{array}$ & $\begin{array}{c}1567.68 \\
(24 \%)\end{array}$ & $\begin{array}{c}380.44 \\
(28.3 \%)\end{array}$ & $\begin{array}{l}2591.36 \\
(26.5 \%)\end{array}$ & $\begin{array}{l}5447.58 \\
(26.1 \%)\end{array}$ & $\begin{array}{l}1477.57 \\
(26.5 \%)\end{array}$ & 0.0099 \\
\hline & $\begin{array}{c}470.21 \\
(14.7 \%) \\
\end{array}$ & $\begin{array}{c}662.62 \\
(10.1 \%) \\
\end{array}$ & $\begin{array}{r}177.39 \\
(13.2 \%) \\
\end{array}$ & $\begin{array}{l}1261.57 \\
(12.9 \%) \\
\end{array}$ & $\begin{array}{l}2571.79 \\
(12.3 \%) \\
\end{array}$ & $\begin{array}{c}690.04 \\
(12.4 \%)\end{array}$ & 0.0021 \\
\hline & \begin{tabular}{|l|}
1136.31 \\
$(35.4 \%)$
\end{tabular} & $\begin{array}{l}2108.48 \\
\text { (32.3\%) }\end{array}$ & $\begin{array}{l}452.75 \\
\text { (33.6\%) }\end{array}$ & $\begin{array}{l}3266.7 \\
(33.3 \%)\end{array}$ & $\begin{array}{l}6964.24 \\
(33.3 \%)\end{array}$ & $\begin{array}{l}1891.32 \\
(33.9 \%)\end{array}$ & 0.0127 \\
\hline
\end{tabular}




\begin{tabular}{|c|c|c|c|c|c|c|c|}
\hline & & & & & & & \\
\hline t & $\begin{array}{l}2016.84 \\
(62.9 \%)\end{array}$ & $\begin{array}{l}3864.42 \\
(59.1 \%)\end{array}$ & $\begin{array}{c}778.79 \\
(57.9 \%)\end{array}$ & $\begin{array}{l}6027.29 \\
(61.5 \%)\end{array}$ & $\begin{array}{c}12687.34 \\
(60.8 \%)\end{array}$ & $\begin{array}{l}3429.81 \\
(61.6 \%)\end{array}$ & 0.0166 \\
\hline 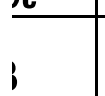 & $\begin{array}{c}2179.74 \\
(68 \%)\end{array}$ & $\begin{array}{l}4473.09 \\
(68.5 \%)\end{array}$ & $\begin{array}{c}923.23 \\
(68.6 \%)\end{array}$ & $\begin{array}{l}6739.93 \\
(68.8 \%)\end{array}$ & $\begin{array}{c}14315.99 \\
(68.5 \%)\end{array}$ & $\begin{array}{l}3807.33 \\
(68.3 \%)\end{array}$ & 0.0048 \\
\hline a- & $\begin{array}{l}2033.15 \\
(63.4 \%)\end{array}$ & $\begin{array}{l}(00.070) \\
3832.74 \\
(58.7 \%)\end{array}$ & $\begin{array}{c}(00.070) \\
905.14 \\
(67.3 \%)\end{array}$ & $\begin{array}{l}(0.01 .78) \\
(61.7 \%)\end{array}$ & $\begin{array}{c}12812.82 \\
(61.4 \%)\end{array}$ & $\begin{array}{l}3462.48 \\
(62.1 \%)\end{array}$ & 0.0164 \\
\hline or & $\begin{array}{c}835.94 \\
(26.1 \%)\end{array}$ & $\begin{array}{l}1555.98 \\
(23.8 \%)\end{array}$ & $\begin{array}{c}260.29 \\
(19.3 \%)\end{array}$ & $\begin{array}{c}2647.44 \\
(27 \%)\end{array}$ & $\begin{array}{l}5299.65 \\
(25.4 \%)\end{array}$ & $\begin{array}{l}1421.74 \\
(25.5 \%)\end{array}$ & 0.0032 \\
\hline in & $\begin{array}{l}1524.64 \\
(47.5 \%) \\
\end{array}$ & $\begin{array}{l}2787.22 \\
(42.7 \%) \\
\end{array}$ & $\begin{array}{c}662.45 \\
(49.2 \%) \\
\end{array}$ & $\begin{array}{l}4428.17 \\
(45.2 \%) \\
\end{array}$ & $\begin{array}{c}9402.48 \\
(45 \%) \\
\end{array}$ & $\begin{array}{l}2467.58 \\
(44.3 \%) \\
\end{array}$ & 0.0150 \\
\hline $\bar{\Gamma}$ & $\begin{array}{c}557.85 \\
(17.4 \%)\end{array}$ & $\begin{array}{c}1634.37 \\
(25 \%)\end{array}$ & $\begin{array}{c}163.4 \\
(12.1 \%)\end{array}$ & $\begin{array}{l}2288.62 \\
(23.4 \%)\end{array}$ & $\begin{array}{l}4644.24 \\
(22.2 \%)\end{array}$ & $\begin{array}{l}1275.11 \\
(22.9 \%)\end{array}$ & 0.0156 \\
\hline of & $\begin{array}{l}1464.25 \\
(45.7 \%)\end{array}$ & $\begin{array}{l}3276.26 \\
(50.1 \%)\end{array}$ & $\begin{array}{c}551.96 \\
(41 \%)\end{array}$ & $\begin{array}{l}4424.87 \\
(45.2 \%)\end{array}$ & $\begin{array}{l}9717.34 \\
(46.5 \%)\end{array}$ & $\begin{array}{l}2605.79 \\
(46.8 \%)\end{array}$ & 0.0047 \\
\hline & $\begin{array}{l}1213.44 \\
(37.8 \%)\end{array}$ & $\begin{array}{l}2703.68 \\
(41.4 \%)\end{array}$ & $\begin{array}{l}443.81 \\
(33 \%)\end{array}$ & $\begin{array}{l}3613.42 \\
(36.9 \%)\end{array}$ & $\begin{array}{l}7974.35 \\
(38.2 \%)\end{array}$ & $\begin{array}{l}2150.56 \\
(38.6 \%)\end{array}$ & 0.0085 \\
\hline iide & $\begin{array}{l}316.99 \\
(9.9 \%)\end{array}$ & $\begin{array}{l}545.52 \\
(8.4 \%)\end{array}$ & $\begin{array}{l}104.16 \\
(7.7 \%)\end{array}$ & $\begin{array}{l}941.11 \\
(9.6 \%)\end{array}$ & $\begin{array}{c}1907.78 \\
(9.1 \%)\end{array}$ & $\begin{array}{l}524.66 \\
(9.4 \%)\end{array}$ & 0.0098 \\
\hline of & $\begin{array}{c}327.99 \\
(10.2 \%) \\
\end{array}$ & $\begin{array}{c}675.87 \\
(10.3 \%) \\
\end{array}$ & $\begin{array}{l}110.92 \\
(8.2 \%)\end{array}$ & $\begin{array}{l}954.94 \\
(9.8 \%) \\
\end{array}$ & $\begin{array}{c}2069.72 \\
(9.9 \%)\end{array}$ & $\begin{array}{c}564.11 \\
(10.1 \%) \\
\end{array}$ & 0.0072 \\
\hline of & $\begin{array}{c}187.7 \\
(5.9 \%)\end{array}$ & $\begin{array}{c}380.2 \\
(5.8 \%)\end{array}$ & $\begin{array}{c}64.64 \\
(4.8 \%)\end{array}$ & $\begin{array}{l}470.95 \\
(4.8 \%)\end{array}$ & $\begin{array}{c}1103.49 \\
(5.3 \%)\end{array}$ & $\begin{array}{l}294.35 \\
(5.3 \%)\end{array}$ & 0.0001 \\
\hline ulin & $\begin{array}{c}981.92 \\
(30.6 \%)\end{array}$ & $\begin{array}{l}1499.29 \\
(22.9 \%)\end{array}$ & $\begin{array}{c}316.6 \\
(23.5 \%)\end{array}$ & $\begin{array}{l}2823.21 \\
(28.8 \%)\end{array}$ & $\begin{array}{l}5621.01 \\
(26.9 \%)\end{array}$ & $\begin{array}{c}1541.1 \\
(27.7 \%)\end{array}$ & 0.0168 \\
\hline of & $\begin{array}{l}62.44 \\
(2 \%)\end{array}$ & $\begin{array}{c}52.38 \\
(0.8 \%)\end{array}$ & $\begin{array}{c}48.25 \\
(3.6 \%)\end{array}$ & $\begin{array}{l}109.87 \\
(1.1 \%)\end{array}$ & $\begin{array}{l}272.94 \\
(1.3 \%)\end{array}$ & $\begin{array}{c}19.75 \\
(0.4 \%)\end{array}$ & 0.1057 \\
\hline
\end{tabular}

The abbreviations as in Table 1

\section{Figures}




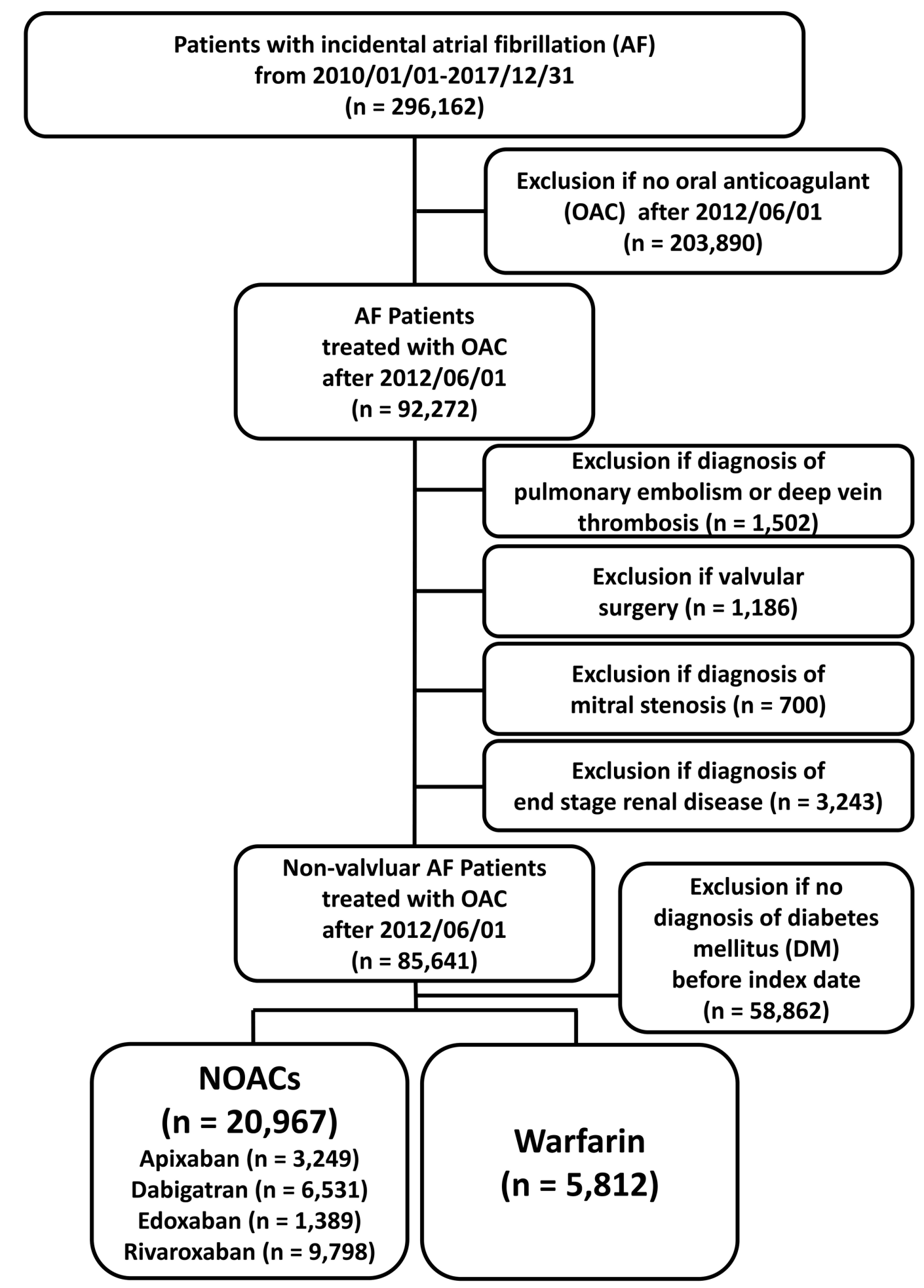

Figure 1

Enrollment of patients with concomitant non-vlavular atrial fibrillation (AF) and diabetes mellitus (DM). From June 1, 2012, to December 31, 2017, a total of 3,249 (16\%), 6,531 (31\%), 1,389 (6\%), and 9,798 (47\%) nonvalvular AF patients comorbid with DM taking apixaban, dabigatran, edoxaban, and rivaroxaban and 5,812 consecutive patients taking warfarin were enrolled in the present study. Abbreviations: AF = atrial fibrillation; $\mathrm{DM}=$ diabetes mellitus; $\mathrm{NOAC}=$ non-vitamin $\mathrm{K}$ antagonist oral anticoagulant; $\mathrm{OAC}=$ oral anticoagulant 


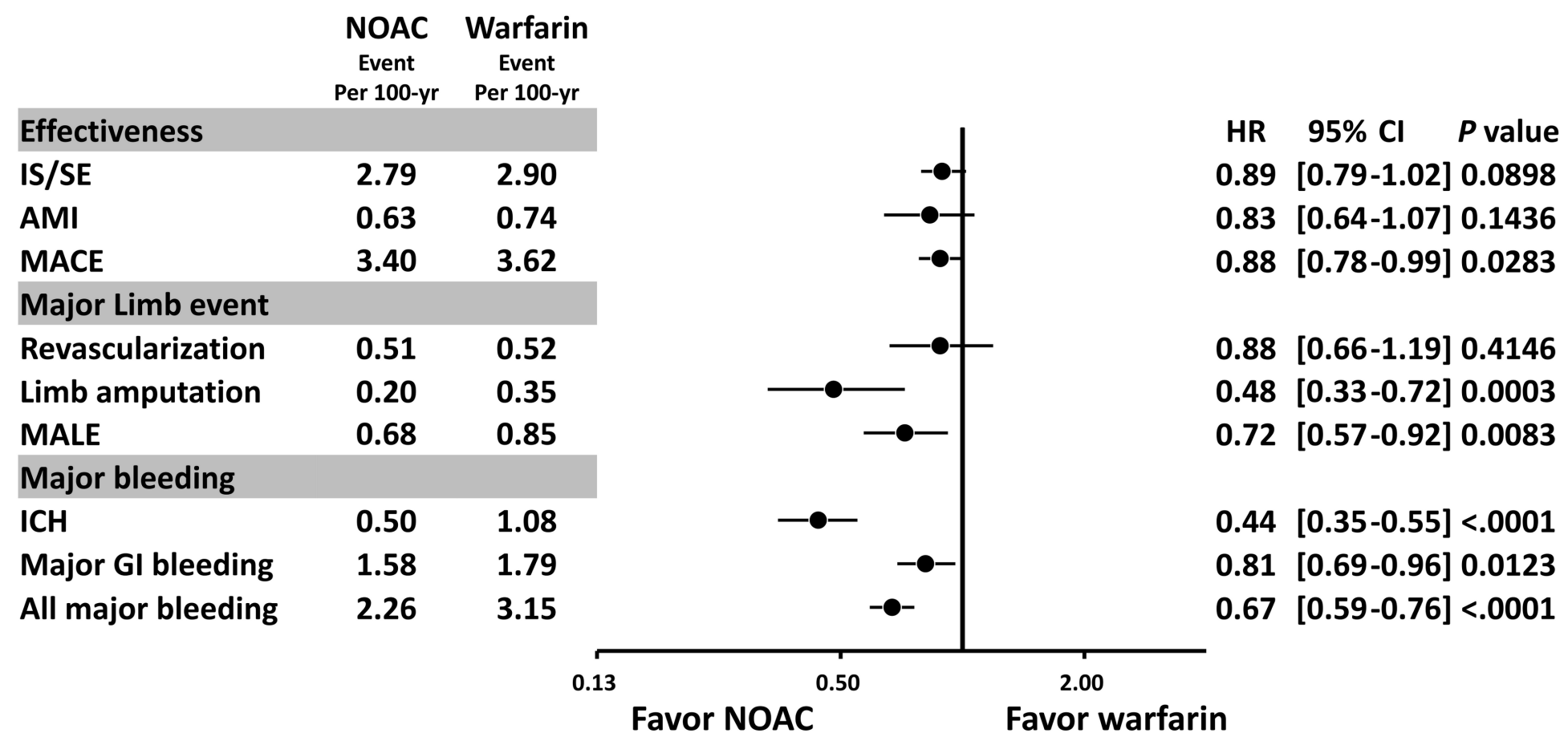

Figure 2

Forest plot of hazard ratio (HR) of effectiveness, major lower limb outcomes, and safety outcomes for NOACs vs. warfarin among non-valvular AF patients comorbid with DM after propensity score stabilized weighting (PSSW). NOAC was associated with a lower risk of major adverse cardiovascular events (MACE), major adverse limb events (MALE), and major bleeding than warfarin among non-valvular AF patients with concomitant DM.Abbreviations: $\mathrm{AF}=$ atrial fibrillation; $\mathrm{AMI}=$ acute myocardial infarction; $\mathrm{Cl}=$ confidential interval; $\mathrm{GI}$ = gastrointestinal; $\mathrm{HR}$ = hazard ratio; $\mathrm{ICH}$ = intracranial hemorrhage; IS = ischemic stroke; $\mathrm{MACE}=$ major adverse cardiovascular events; MALE = major adverse limb events; NOAC = non-vitamin K antagonist oral anticoagulants; $\mathrm{SE}=$ systemic embolism; PSSW = propensity score stabilized weighting 


\begin{tabular}{|c|c|c|c|c|c|c|c|c|}
\hline & $\begin{array}{l}\text { NOAC } \\
\text { Event } \\
\text { Per 100-yr }\end{array}$ & $\begin{array}{l}\text { Warfarin } \\
\text { Event } \\
\text { Per 100-yr }\end{array}$ & & & & & & \multirow[b]{2}{*}{$\mathbf{P}$ interaction } \\
\hline IS/SE & & & & & HR & $95 \% \mathrm{Cl}$ & $P$ value & \\
\hline All NOACs & 2.79 & \multirow[t]{5}{*}{2.90} & $-\bullet-$ & & 0.89 & [0.79-1.02] & 0.0898 & \multirow{5}{*}{0.36} \\
\hline Apixaban & 2.71 & & $\longrightarrow-$ & & 0.76 & {$[0.60-0.95]$} & $0.0187]$ & \\
\hline Dabigatran & 2.69 & & $-\bullet$ & $t$ & 0.93 & {$[0.80-1.08]$} & 0.3145 & \\
\hline Edoxaban & 3.28 & & $\longrightarrow$ & $t$ & 0.70 & [0.45-1.10] & 0.1261 & \\
\hline Rivaroxaban & 2.87 & & $-\bullet-$ & $t$ & 0.91 & {$[0.79-1.05]$} & 0.2155 & \\
\hline \multicolumn{8}{|l|}{ AMI } & \multirow{6}{*}{0.40} \\
\hline All NOACs & 0.63 & \multirow[t]{5}{*}{0.74} & $\longrightarrow-$ & $t$ & 0.83 & [0.64-1.07] & 0.1436 & \\
\hline Apixaban & 0.66 & & $\longrightarrow-$ & + & 0.79 & {$[0.50-1.27]$} & 0.33681 & \\
\hline Dabigatran & 0.60 & & $\rightarrow-$ & $t$ & 0.82 & {$[0.60-1.11]$} & 0.1981 & \\
\hline Edoxaban & 0.18 & & & - & 0.18 & [0.03-1.15] & 0.0701 & \\
\hline Rivaroxaban & 0.67 & & $\longrightarrow-$ & - & 0.87 & {$[0.65-1.16]$} & $0.3403]$ & \\
\hline \multicolumn{8}{|l|}{ MACE } & \multirow{6}{*}{0.20} \\
\hline All NOACs & 3.40 & 3.62 & $-\bullet-$ & & 0.88 & [0.78-0.99] & 0.0283 & \\
\hline Apixaban & 3.36 & & $\longrightarrow-$ & & 0.76 & {$[0.62-0.94]$} & 0.01011 & \\
\hline Dabigatran & 3.29 & & & & 0.90 & {$[0.79-1.04]$} & 0.1511 & \\
\hline Edoxaban & 3.46 & & $\longrightarrow$ & & 0.61 & {$[0.39-0.94]$} & 0.0260 & \\
\hline \multirow[t]{2}{*}{ Rivaroxaban } & 3.51 & & $-\rightarrow-$ & & 0.90 & {$[0.79-1.02]$} & $0.1099]$ & \\
\hline & & 0.13 & Favor NOAC & $\begin{array}{l}2.00 \\
\text { Favor warfarin }\end{array}$ & & & & \multirow{7}{*}{$\mathbf{P}$ interaction } \\
\hline \multicolumn{2}{|c|}{ Revascularization } & & & & HR & $95 \% \mathrm{Cl}$ & $P$ value & \\
\hline All NOACs & 0.51 & \multirow[t]{5}{*}{0.52} & $\longrightarrow-$ & - & 0.88 & [0.66-1.19] & 0.4146 & \\
\hline Apixaban & 0.57 & & - & 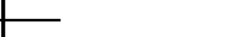 & 0.85 & {$[0.51-1.41]$} & 0.52751 & \\
\hline Dabigatran & 0.47 & & $\longrightarrow$ & - & 0.90 & [0.63-1.28] & 0.5444 & \\
\hline Edoxaban & 0.60 & & 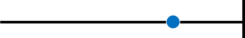 & & 0.65 & {$[0.23-1.87]$} & 0.4279 & \\
\hline Rivaroxaban & 0.52 & & $\longrightarrow-$ & + & 0.89 & {$[0.64-1.25]$} & $0.5146]$ & \\
\hline \multicolumn{8}{|c|}{ Lower limb amputation } & \multirow{6}{*}{0.75} \\
\hline All NOACs & 0.20 & 0.35 & $\longrightarrow$ & & 0.48 & {$[0.33-0.72]$} & 0.0003 & \\
\hline Apixaban & 0.31 & & $\longrightarrow$ & 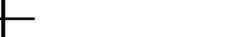 & 0.62 & [0.31-1.21] & $0.1569]$ & \\
\hline Dabigatran & 0.19 & & $\longrightarrow$ & & 0.52 & {$[0.32-0.86]$} & 0.0107 & \\
\hline Edoxaban & 0.16 & $/ /-$ & & & 0.23 & {$[0.03-1.66]$} & 0.1465 & \\
\hline Rivaroxaban & 0.18 & & $\longrightarrow-$ & & 0.44 & {$[0.27-0.70]$} & $0.0007]$ & \\
\hline \multicolumn{8}{|l|}{ MALE } & \multirow{7}{*}{0.81} \\
\hline All NOACs & 0.68 & 0.85 & $\longrightarrow$ & & 0.72 & {$[0.57-0.92]$} & 0.0083 & \\
\hline Apixaban & 0.89 & & $-\longrightarrow$ & - & 0.78 & {$[0.52-1.18]$} & 0.23961 & \\
\hline Dabigatran & 0.64 & & & & 0.76 & {$[0.57-1.01]$} & 0.0613 & \\
\hline Edoxaban & 0.76 & & - & - & 0.49 & {$[0.19-1.23]$} & 0.1288 & \\
\hline Rivaroxaban & 0.66 & & $\longrightarrow-$ & & 0.70 & {$[0.53-0.92]$} & $0.0106]$ & \\
\hline & & 0.13 & Favor NOAC & Favor warfarin & & & & \\
\hline ICH & & & & & HR & $95 \% \mathrm{Cl}$ & $P$ value & $\mathbf{P}$ interaction \\
\hline All NOACs & 0.50 & 1.08 & $\longrightarrow-$ & & 0.44 & {$[0.35-0.55]$} & $<.0001$ & \\
\hline Apixaban & 0.61 & & & & 0.49 & {$[0.30-0.77]$} & 0.00241 & \\
\hline Dabigatran & 0.40 & & $\longrightarrow$ & & 0.37 & {$[0.27-0.51]$} & $<.0001$ & \\
\hline Edoxaban & 0.86 & & & & 0.50 & [0.19-1.29] & 0.1536 & 0.61 \\
\hline Rivaroxaban & 0.55 & & $\longrightarrow$ & & 0.48 & {$[0.37-0.63]$} & $<.0001]$ & \\
\hline Major GI blee & ing & & & & & & & \\
\hline All NOACs & 1.58 & 1.79 & $\longrightarrow-$ & & 0.81 & [0.69-0.96] & 0.0123 & \\
\hline Apixaban & 1.76 & & $\longrightarrow \longrightarrow$ & & 0.78 & {$[0.59-1.05]$} & 0.10021 & \\
\hline Dabigatran & 1.23 & & $\longrightarrow-$ & & 0.68 & {$[0.56-0.84]$} & 0.0003 & \\
\hline Edoxaban & 3.01 & & & & 1.09 & {$[0.68-1.76]$} & 0.7229 & 0.11 \\
\hline Rivaroxaban & 1.78 & & $\rightarrow-$ & $t$ & 0.90 & [0.75-1.09] & 0.2828 & \\
\hline All major blee & ing & & & & & & & \\
\hline All NOACs & 2.26 & 3.15 & $-\bullet-$ & & 0.67 & {$[0.59-0.76]$} & $<.0001$ & \\
\hline Apixaban & 2.55 & & $\longrightarrow$ & & 0.66 & {$[0.52-0.84]$} & 0.00071 & \\
\hline Dabigatran & 1.81 & & $\longrightarrow-$ & & 0.57 & {$[0.49-0.68]$} & $<.0001$ & \\
\hline Edoxaban & 4.20 & & & & 0.88 & [0.58-1.32] & 0.5245 & 0.06 \\
\hline Rivaroxaban & 2.50 & & $-\bullet$ & & 0.73 & {$[0.63-0.85]$} & $<.0001]$ & \\
\hline & & 0.13 & Favor NOAC & $\begin{array}{c}2.00 \\
\text { Favor } \mathrm{W}\end{array}$ & & & & \\
\hline
\end{tabular}

\section{Figure 3}

Forest plot of HR of effectiveness, major lower limb outcomes, and safety outcomes for each NOAC vs. warfarin among non-valvular AF patients with concomitant DM taking oral anticoagulants after PSSW. In general, the advantage of effectiveness, major adverse limb outcome, and safety for NOAC over warfarin persisted in four NOACs (P interaction all > .05). The abbreviations as in Figure 2 


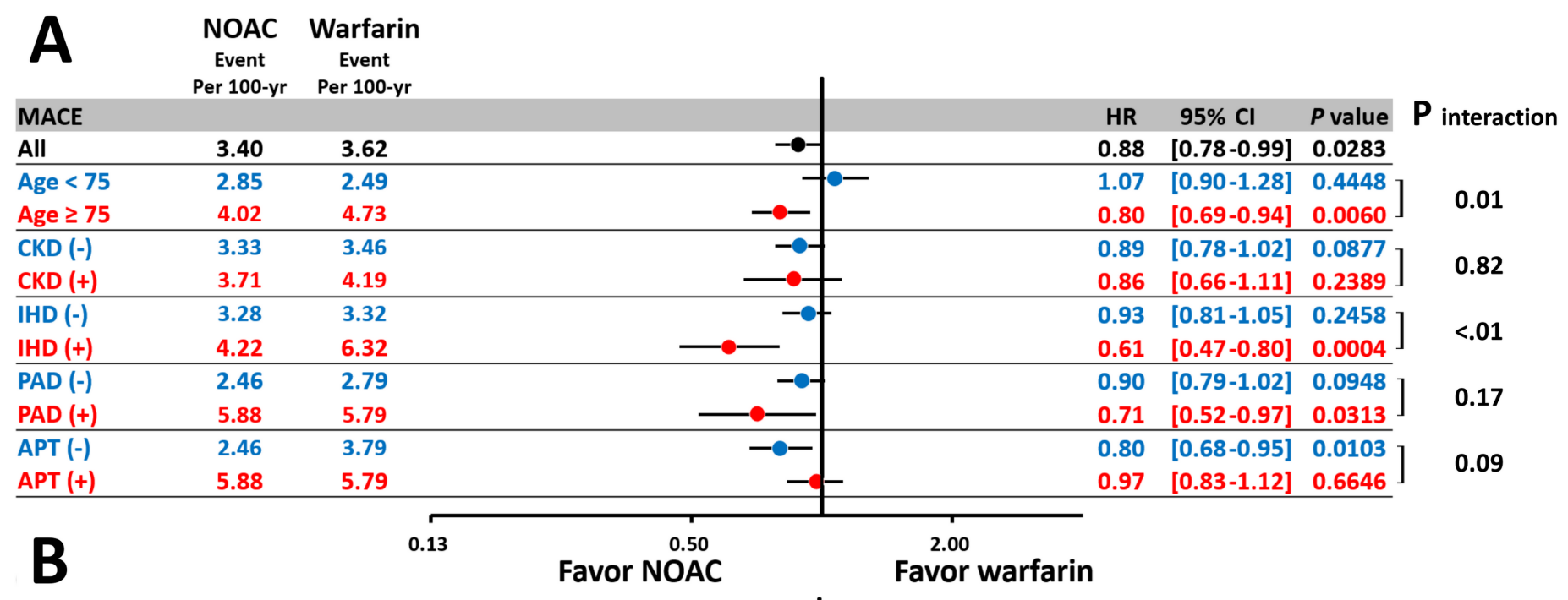

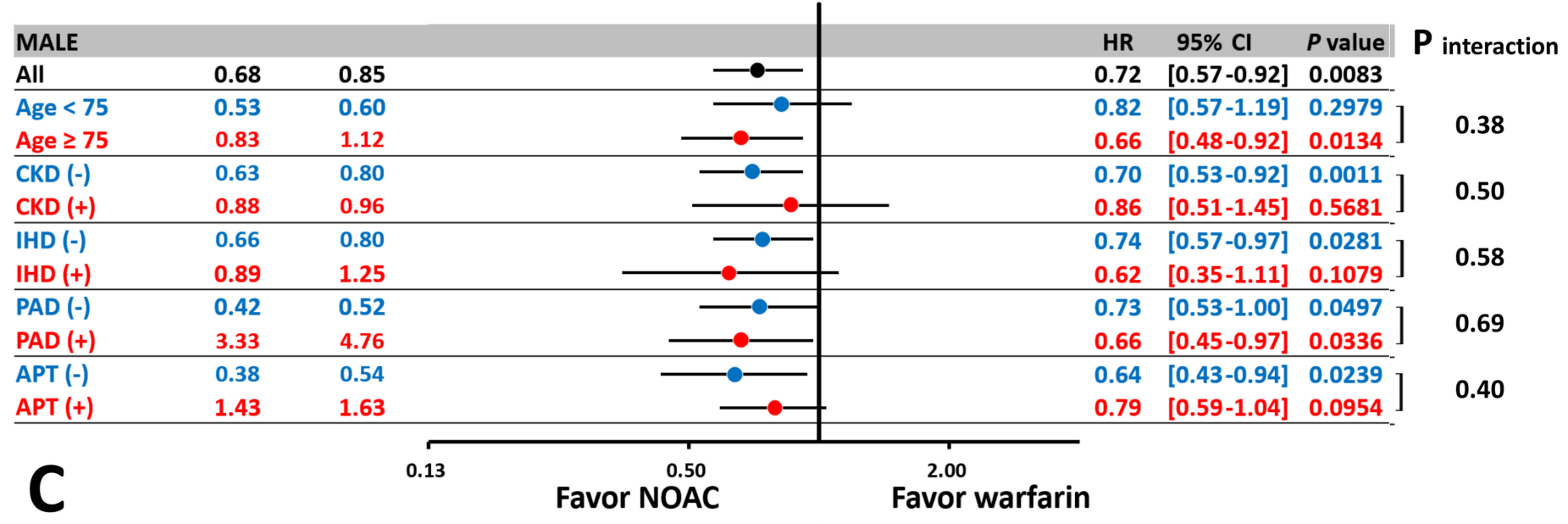

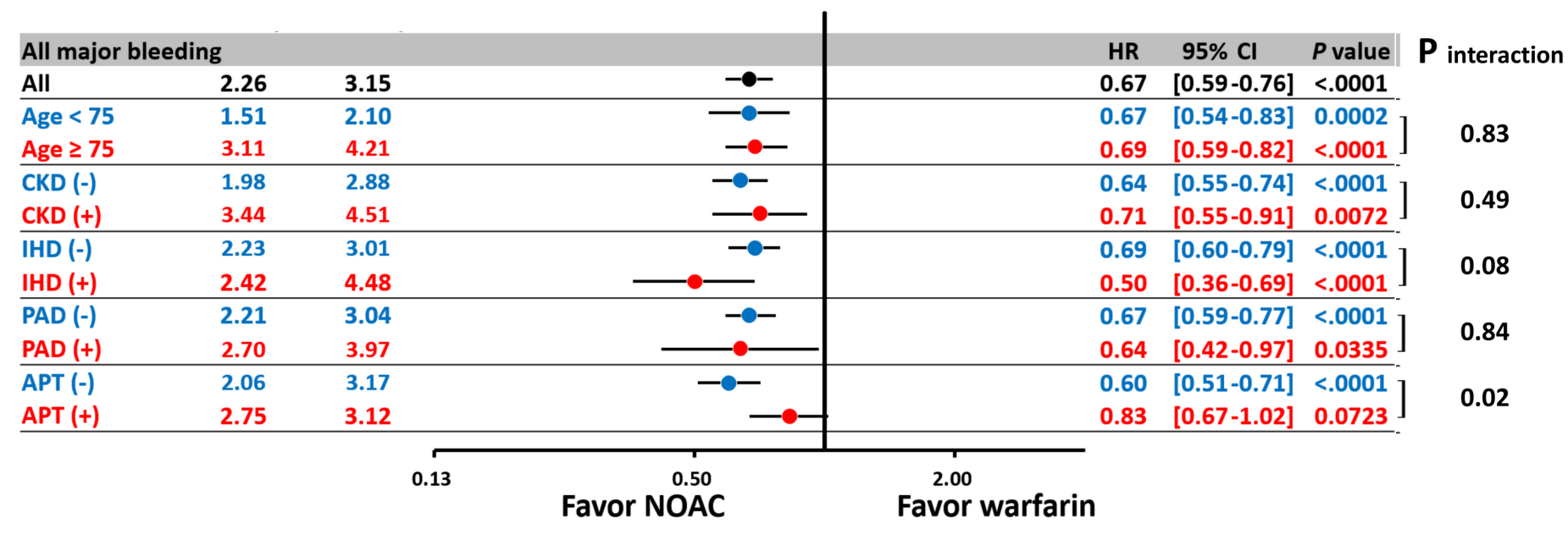

Figure 4

Subgroup analysis of forest plot of HR for NOAC vs. warfarin among non-valvular AF patients with concomitant DM after PSSW. In general, the subgroup analysis showed consistent results for MACE, MALE, and major bleeding for NOACs vs. warfarin among those patients with $\geq 75$ years of age, the presence of chronic kidney disease (CKD), ischemic heart disease (IHD), peripheral artery disease (PAD), and use of concomitant antiplatelet agent (APT) as the main analysis. Furthermore, NOAC reduced MACE more in diabetic AF patients with a high atherosclerotic burden including elderly, the presence of IHD or PAD. 
Abbreviations: $\mathrm{APT}$ = antiplatelet agent; $\mathrm{CKD}=$ chronic kidney disease; $\mathrm{IHD}=$ ischemic heart disease; $\mathrm{PAD}=$ peripheral artery disease Other abbreviations as in Figure 2

\section{Supplementary Files}

This is a list of supplementary files associated with this preprint. Click to download.

- DMAFDOACSuppIMaterial20200123.doc 